\title{
ECHOCARDIOGRAPHIC CHARACTERISTIC OF LEFT VENTRICULAR GEOMETRY OF 12-17 YEARS ATHLETES
}

\author{
Aldona Bartkevičienè $\dot{1}^{1,2}$ \\ ${ }^{1}$ Klaipéda university hospital, Lithuania, ${ }^{2}$ Klaipèda University, Lithuania
}

Key words: children, athletes, left ventricle, geometry, hypertrophy.

\begin{abstract}
Summary
Aim. To compare the type of left ventricular geometry associated with training among 12-17 years athletes currently competing in cycling, rowing and basketball playing and to determine the factors influencing left ventricular geometry.

Methods. A total 167 male athletes 12-17 year-old, involved in basketball $(\mathrm{n}=62)$, academic rowing $(\mathrm{n}=51)$ and cycling $(\mathrm{n}=54)$ and 168 sedentary non-athletes, matched for age and sex were involved in this study. All participants underwent twodimensional, M-mode and Doppler echocardiography. To estimate left ventricular geometry relative wall thickness and left ventricular mass index were calculated. Left ventricular geometry was assessed as normal, eccentric ventricular hypertrophy, concentric left ventricular hypertrophy, concentric left ventricular remodeling. Results. Left ventricular hypertrophy was present in $48 \%$ of all athletes, predominantly (34\%) eccentric hypertrophy. $16 \%$ of athletes had concentric hypertrophy. Only $7 \%$ of athletes manifested concentric remodeling. The prevalence of eccentric hypertrophy was more common in cyclists (54\%), concentric hypertrophy was more frequent in rowers (38\%), and normal left ventricular geometry was more common in basketball players (53\%). Multivariate regression analysis showed that age was the important determinant of eccentric and concentric left ventricular hypertrophy. Eccentric left ventricular hypertrophy also was independently associated to training volume (hour per week) and cycling sporting discipline. Conclusion. Almost half of athletes (48\%) had left ventricular hypertrophy, predominantly eccentric hypertrophy, and the age was the important determinant of
\end{abstract}

left ventricular hypertrophy (eccentric and concentric). Training volume and cycling sporting discipline were significantly associated with eccentric left ventricular hypertrophy.

\section{Introduction}

Long-term physical load is associated with remodeling of cardiac geometry referred as physiological left ventricular hypertrophy or 'athlete's heart' $(4,19,22,26,29)$. Most studies showed that the accompanying echocardiographic changes depend on the type of exercise undertaken $(1,5$, $10,12,22$ ). More isotonic (anisometric) forms of exercise found in endurance sports can cause an increase in ventricular chamber dimensions, but with only mild but proportional increases in wall thickness. In contrast, anisometric exercise, found in the predominantly strength trained sports, tend to increase wall thickness alone. Endurance sports like cycling and rowing combines dynamic and static exercise, imposing components of unique cardiac demand on athletes participating in this activity. Apart technical skills, basketball training involves predominantly dynamic, both aerobic and anaerobic, and static exercises $(5,10)$.

Adult athletes who undertake both isometric and anisometric forms of exercise, have been found to have increased wall thickness, chamber dimensions and left ventricular mass compare with healthy non- athletes, but despite the fact that more and more children are engaged in intensive training programs, there is the lack of studies on adolescent players $(3,15,16,20,21)$. Much less, cardiovascular system in athletic children and adolescents is influenced not only by physical load, but also by rapid body growth and maturation (26). Such changes are important as they may simulate pathological forms of hypertrophy - hypertrophic and dilated cardiomyopathy - causing sudden death in the athletic population, and inspire anxiety among athletes with possible exclusion from sport $(19,22)$.

In this study we investigated three groups of 12-17 years athletes, i.e. cyclists, rowers and basketball players. To 
our knowledge, studies comparing left ventricular geometry in such kind of different sports do not exist. Therefore, our purpose was to compare the type of left ventricular geometry associated with training among 12-17 years athletes currently competing in cycling, rowing and basketball playing and to determine the factors influencing left ventricular geometry.

The aim of the study: To compare the type of left ventricular geometry associated with training among 12-17 years athletes currently competing in cycling, rowing and basketball playing and to determine the factors influencing left ventricular geometry.

\section{Materials and methods}

The study protocol was approved by Regional Ethics Committee for Biomedical Research. The subjects participated in the study after being informed subjects and their parents about testing procedures, possible risks and discomfort, and subsequently providing signed informed consent in accordance with the Helsinki Declaration.

A total of 167 athletes with a mean age of 14.8 (1.6) years (range 12-17 years) and 168 nonathletic controls with a mean age of 14.8 (1.4) years (range 12-17) were enrolled into the study. The control group comprised healthy non-athletes volunteers who were pupils at the secondary schools. They were not participated in additional sports activities outside of physical education classes in school during the last years; their weekly physical activity was less 2 hours. Any cardiac or systemic pathology was ruled out by physical examination made by a general practice physician. There were no significant age, height, weight, body surface area and body mass index differences between athletes and controls.

According the sporting discipline the athletes were divided into three groups as follows: basketball players $(\mathrm{n}=62)$, rowers $(\mathrm{n}=51)$ and cyclists $(\mathrm{n}=54)$. According the age participants were divided into three age subgroups: $12-13$ years, $14-15$ years, and $16-17$ years. Athletes were competitors of variable ability; the most of them belonged to various regional teams, $15(8.9 \%)$ athletes were members of the national team. None of the athletes had any car-

Table 1. Characteristics of 167 athletes undergoing echocardiography Value are mean (SD, standard deviation); BSA, body surface area

\begin{tabular}{|l|c|c|c|c|}
\hline \multirow{2}{*}{ Characteristic } & $\begin{array}{c}\text { Basketball players, } \\
\mathbf{n = 6 2}\end{array}$ & $\begin{array}{c}\text { Rowers, } \\
\mathbf{n = 5 1}\end{array}$ & $\begin{array}{c}\text { Cyclists, } \\
\mathbf{n = 5 4}\end{array}$ & \multirow{2}{*}{$\mathbf{p}<\mathbf{0 . 0 5}$} \\
\cline { 2 - 4 } & $\mathbf{B}$ & $\mathbf{R}$ & $\mathbf{C}$ & \\
\hline Age, yr & $14.9(1.4)$ & $14.9(1.7)$ & $14.7(7.4)$ & - \\
\hline Height, cm & $178.7(11.4)$ & $176.9(8.5)$ & $172.1(9.8)$ & $\mathrm{B}>\mathrm{C}$ \\
\hline Weight, kg & $66.7(14.5)$ & $65.6(12.5)$ & $59.2(12.1)$ & $\mathrm{B}>\mathrm{C}$ \\
\hline BSA, $\mathrm{m}^{2}$ & $1.81(0.24)$ & $1.78(0.21)$ & $1.67(0.22)$ & $\mathrm{C}<\mathrm{B}, \mathrm{R}$ \\
\hline
\end{tabular}

diac and systemic diseases on the basis of negative medical history and detailed physical examination, none had acute diseases acquired one month before the study and during it, and none had trauma experienced during the last 3 months before the study and during it. No athlete was taking any medication. The number of hours of intensive training for last 12 months averaged 9.5 \pm 3.9 hours a week (range 4-30 hours). Average training duration was $3.2 \pm 2.2$ years (range $0.3-10$ years). The training duration of basketball players was longer than of rowers and cyclists $(p<0.05)$. Rowers training volume was greater than basketball players $(p<0.05-$ Table 1). Examination included measurement of height and weight and echocardiography. All tests were applied to subjects on different three days.

Echocardiography study. Standard two-dimensional transthoracic echocardiograms were recorded using a Philips sonograph with a $3.5 \mathrm{MHz}$ transducer, in the left lateral decubitus position. Echocardiographic studies were carried out by the same cardiologist. Three consecutive measures of every parameter were made and the average was taken by the investigator. All measurements were performed according to the recommendations of the American College of Cardiology and the American Society of Echocardiography (13). Two-dimensionally targeted M-mode images in the pasternal long axis at the tips of the mitral valve leaftlets were used to measure the following echocardiographic parameters at end diastole: interventricular septal thickness at diastole (IVSTd), left ventricular internal diameter at end diastole (LVIDd), left ventricular internal diameter at end systole (LVIDs) and left ventricular posterior wall thickness (LVPWTd). Left ventricular mass (LVM) was calculated by applying the modified Devereux formula accepted by the Penn Convention (Devereux et al.): LVM $=0.8 \times\left[1.04\left\{(\text { LVIDd }+ \text { LVPWTd }+ \text { IVSTd })^{3}-\right.\right.$ LVIDd $\left.\left.^{3}\right\}\right]$ +0.6 g., where LVIDd, indicates left ventricular internal diameter at end diastole, LVPWTd, left ventricular posterior wall thickness at end diastole; IVSTd, interventricular septal thickness at end diastole; LVPWTd, left ventricular posterior wall thickness at end diastole.

Relative left ventricular wall thickness (RWT) was calculated using the following formula: RWT $=($ IVSTd + LVPWTd)/LVIDd, where IVSTd indicates interventricular septal thickness at end diastole; LVPWTd, left ventricular posterior wall thickness at end diastole; LVIDd, left ventricular internal diameter at end diastole.

LVMI was derived by dividing LVM in grams by the subject's height in meters raised to the 2.7 power $(7,8,15,16,31)$. 
LVMI and was used to evaluate LV hypertrophy adjusted to body size. 95th percentile of relative wall thickness (95th percentile $=0.41$ ) and left ventricular mass index mass index (95th percentile $=95.69 \mathrm{~kg} / \mathrm{m}^{2}$ ), from control subjects were used as cut-points $(7,8)$. In the assessment of left ventricular remodeling pattern, based on upper limits for left ventricular mass index and relative wall thickness, normal left ventricular geometry, eccentric remodeling, concentric remodeling and concentric left ventricular hypertrophy were defined $(7,8,11)$. Normal left ventricular geometry was defined when the mean values of left ventricular mass index and relative wall thickness were below the 95th percentile; concentric left ventricular remodeling, when left ventricular mass index was below and relative wall thickness above; left ventricular concentric hypertrophy, when left ventricular mass index and relative wall thickness were above; and eccentric hypertrophy, when left ventricular mass index above and relative wall thickness below the 95th percentile (24). Statistical analysis. Data is presented as means with standard deviations, $95 \%$ confidence interval (CI); categorical variables are presented as counts with percentages. Continuous data were examined for normality and were analyzed using the $t$ test or MannWhitney test. Categorical data were analyzed using Fisher's exact test or chi-square test.

The correlation of the measured data with variables like age, height, weight, body surface area, total and weekly training time (training volume) are analyzed with Spearman's rank correlation and linear regression. A multiple logistic regression analyses were used to determine the independent predictors of left ventricular geometry in athletes; the models included age, body surface area, body mass index, height, weight, height raised to power 2.7, sporting discipline, training volume, training duration. A two-tailed $\mathrm{p}$ value $<0.05$ was considered statistically significant. All statistical analyses were performed using SPSS for Windows 15.0 software.

\section{Results}

There were no differences in anthropometric data between the groups of athletes and controls except for the height, which was higher in basketball players than controls. Comparison of demographic, anthropometric and training data showed that BSA of cyclists was greater than that of basketball players and rowers, training duration of basketball players was longer than of rowers and cyclists, and rowers were engaged in more extensive training than basketball players. All echocardiographic parameters and parameters indexed to body surface area and height were significantly (all $\mathrm{p}<0.001$ ) greater than analogous parameters in the non-athletes group $(\mathrm{p}=0.051)$.

There was a greater percentage difference in interventricular septal thickness at diastole and left ventricular posterior wall thickness than in internal diameter at end diastole between athletes and non-athletes subjects (respectively $14.3 \%$ and $14.2 \%$ versus $5.4 \%$ - Table 2 ).

Left ventricular hypertrophy was present in $56.9 \%(\mathrm{n}=$ $95)$ of the athletes, with $34.1 \%(n=57)$ of all athletes sho-

Table 2. Echocardiographic data concerning athletes and matched untrained controls $C I$, confidence interval; ${ }^{a} D \%$, difference between athletes and controls; ${ }^{b}$ nonparametric Mann-Whitney test.

LVM, left ventricular mass; IVSTd, interventricular septal thickness at end diastole; LVPWTd, left ventricular posterior wall thickness at end diastole; RWT, relative wall thickness; LVIDd, left ventricular internal diameter at end diastole; FS, shortening fraction; E, peak early transmitral flow velocity; $A$, peak late transmitral flow velocity; $E / A$, ratio of $E$ to $A$.

$* p<0.05$ athletes versus control.

\begin{tabular}{|c|c|c|c|c|c|c|}
\hline \multirow{2}{*}{ Parameter } & \multicolumn{2}{|c|}{ Athletes, $\mathrm{n}=167$} & \multicolumn{2}{|c|}{ Controls, $n=168$} & \multirow{2}{*}{$\begin{array}{l}\Delta, \\
\%^{\mathrm{a}}\end{array}$} & \multirow{2}{*}{$p$ value } \\
\hline & Mean & $95 \%$ CI & Mean & $95 \%$ CI & & \\
\hline $\begin{array}{l}\text { LVIDd, } \mathrm{mm} \\
\text { range, } \mathrm{mm}\end{array}$ & $\begin{array}{l}50.16 \\
42-63\end{array}$ & $49.56-50.77$ & $\begin{array}{l}47.59 \\
38-54\end{array}$ & $47.15-48.03$ & 5.4 & $<0.001$ \\
\hline $\begin{array}{l}\text { IVSTd, } \mathrm{mm} \\
\text { range, } \mathrm{mm}\end{array}$ & $\begin{array}{l}9.67 \\
6-13.8\end{array}$ & $9.46-9.88$ & $\begin{array}{l}8.41 \\
6-11 \\
\end{array}$ & $8.25-8.58$ & 14.3 & $<0.001$ \\
\hline $\begin{array}{l}\text { LVPWTd, mm } \\
\text { range, } \mathrm{mm}\end{array}$ & $\begin{array}{l}9.21 \\
6-13\end{array}$ & $9.00-9.42$ & $\begin{array}{l}8.06 \\
6-10.8\end{array}$ & $7.90-8.23$ & 14.2 & $<0.001$ \\
\hline RWT & 0.38 & $0.37-0.38$ & 0.35 & $0.34-0.35$ & 8.5 & $<0.001$ \\
\hline LVM, g & 173.28 & $166.6-180.20$ & 130.98 & $126.6-135.4$ & 32.3 & $<0.001$ \\
\hline LVMI, $\mathrm{g} / \mathrm{m}^{2}$ & 97.70 & $94.73-100.66$ & 75.06 & $73.25-76.87$ & 30.7 & $<0.001$ \\
\hline FS, \% & 38.53 & $38.07-38.99$ & 37.69 & $37.82-38.41$ & 2.2 & $0.028^{\mathrm{b}}$ \\
\hline $\mathrm{E}, \mathrm{m} / \mathrm{s}$ & 1.01 & $0.99-1.03$ & 0.91 & $0.89-0.97$ & 10.9 & $<0.001^{\mathrm{b}}$ \\
\hline $\mathrm{A}, \mathrm{m} / \mathrm{s}$ & 0.52 & $0.50-0.53$ & 0.49 & $0.48-0.50$ & 6.1 & $0.001^{\mathrm{b}}$ \\
\hline $\mathrm{E} / \mathrm{A}$ & 1.99 & $1.94-2.05$ & 1.89 & $1.84-1.93$ & 5.2 & $0.003^{b}$ \\
\hline
\end{tabular}




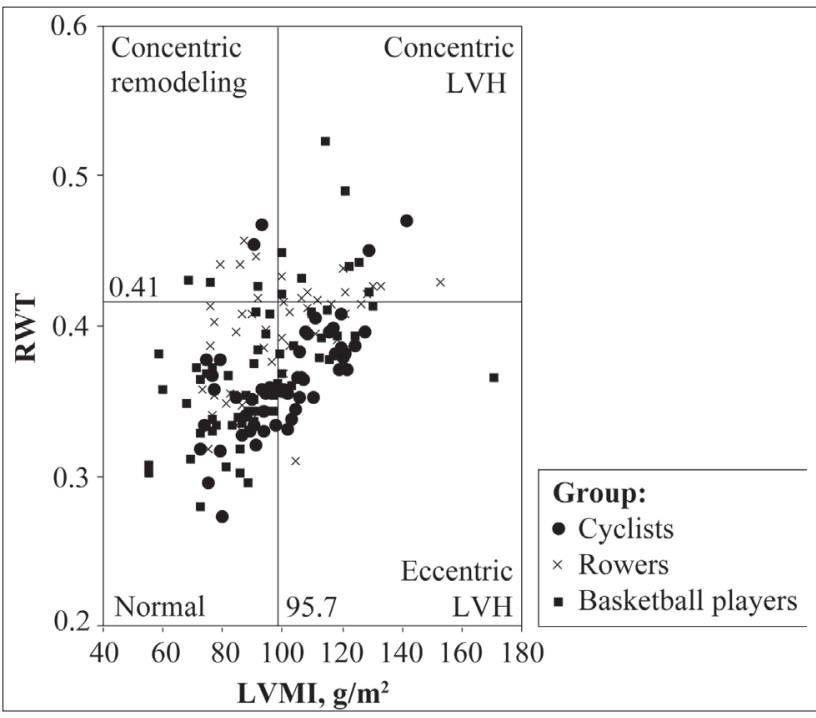

Fig. 1. Distribution of left ventricular mass (LVM) normalized to body surface area and relative wall thickness (RWT) in athletes of different sporting discipline

Notes: Reference lines represent the $95^{\text {th }}$ percentile of $L V M I$ and $R W T$ in control subjects

wing eccentric left ventricular hypertrophy, $16.2 \%(\mathrm{n}=27)$ exhibiting concentric left ventricular hypertrophy and only $6.6 \%(\mathrm{n}=11)$ - concentric remodeling (Fig. 1) The distribution of left ventricular geometry significantly differs according to sporting discipline and age (Fig. $2 \mathrm{~A}$ and B). The prevalence of abnormal left ventricular geometry was slightly higher in rowers and cyclists comparing with basketball players. Normal left ventricular geometry was most prevalent among basketball players (53.2\%). Eccentric hypertrophy was most prevalent among cyclists as compared with concentric hypertrophy $(53.7 \%$ versus $7.4 \%)$. The rowers had concentric hypertrophy and concentric remodeling $(41.2 \%)$ more frequently than eccentric hypertrophy $(23.5 \%)$. Distribution of eccentric and concentric left ventricular hypertrophy in basketball players was nearly similar $(25.8 \%$ versus $20.9 \%)$ (Fig. 2A). Altered left ventricular geometry was most prevalent among $16-17$-year-old athletes $(82.4 \%)$ and least prevalent among 12-13-year-old athletes (12.8\%). Among the athletes aged 12-13 years concentric hypertrophy was not present (remodeling 5.1\%) (Fig. 2B).

Among the multiple factors that correlated with individual echocartion; \# reference category

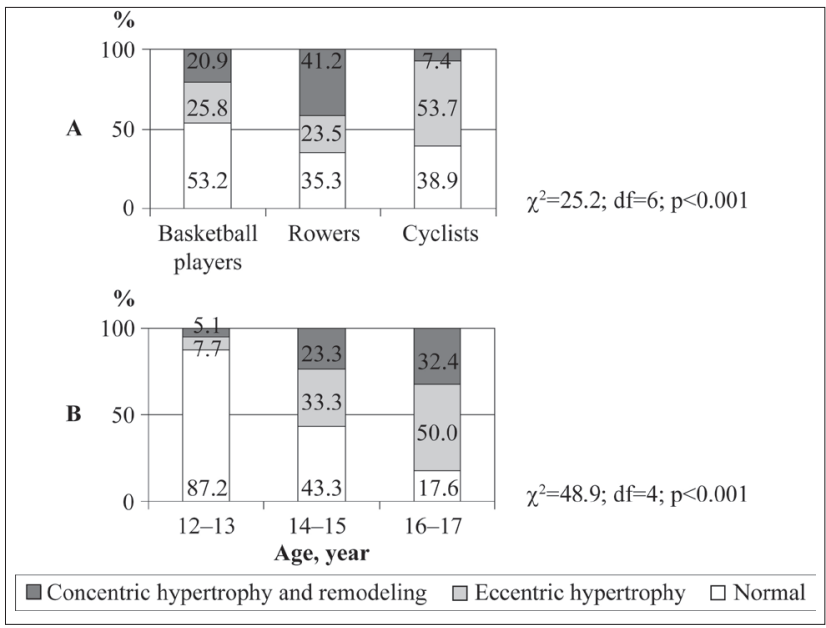

Fig. 2. Distribution of left ventricular geometry in athletes by sporting discipline (A) and age (B)

diographic parameters in the univariate analysis, left ventricular mass index was positively correlated with age $(\mathrm{r}=$ $0.59)$, body surface area $(\mathrm{r}=0.29)$, body mass index $(\mathrm{r}=$ $0.22)$, height $(\mathrm{r}=0.27)$, weight $(\mathrm{r}=0.27)$, training volume $(\mathrm{r}=0.35)$ and duration $(\mathrm{r}=0.28)$, sporting discipline $(\mathrm{r}=$ $0.16)$, and systolic blood pressure at peak exercise $(\mathrm{r}=0.52)$ and at rest $(\mathrm{r}=0.24)($ all $\mathrm{p}<0.01)$. Relative wall thickness was positively related to age $(r=0.45)$, body weight $(r=$ $0.32)$, height $(r=0.27)$, body mass index $(r=0.33)$, body surface area $(r=0.33)$, training volume $(r=0.38)$. After multivariable adjustment (Table 3), an independent association was found between eccentric left ventricular hypertrophy and age (compared to age of 12-13 years in the age of $14-15$ years odd ratio $(\mathrm{OR})=16.3$, in the age of $16-17$ year $\mathrm{OR}=48.6$ ), training volume (each hour per week of

Table 3. Independent predictors of LV geometry in athletes $(\mathrm{N}=167)$

" including $L V$ concentric remodeling; $C I$, confidence interval; OR, odds ratio; $R^{2}$, corrected coefficient of determina-

Controling for age, BSA, body mass index (BMI), height, weight, height ${ }^{27}$, sporting discipline, training volume, training duration, $S B P$ at rest and at peak exercise.

\begin{tabular}{|c|c|c|c|c|}
\hline \multirow{3}{*}{ Predictor } & \multicolumn{4}{|c|}{ Left ventricle geometric pattern } \\
\hline & \multicolumn{2}{|c|}{ Eccentric LV hypertrophy } & \multicolumn{2}{|c|}{ Concentric LV hypertrophya } \\
\hline & OR (95\% CI) & p & OR $(95 \% \mathrm{CI})$ & $\mathbf{p}$ \\
\hline Age, years & & $\mathrm{p}_{\text {for trend }}=0.001$ & & $\mathrm{p}_{\text {fortrend }}=.050$ \\
\hline $12-13^{\#}$ & 1 & & - & - \\
\hline $14-15$ & $16.3(2.9-92.2)$ & 0.002 & $0.3(0.1-0.8)$ & 0.016 \\
\hline $16-17$ & $48.6(3.8-62.4)$ & 0.003 & 1 & \\
\hline Training, h/wk & $2.6(1.04-6.7)$ & 0.042 & & \\
\hline Age*training, yr & $0.7(0.5-1.0)$ & 0.061 & & \\
\hline Sport & & $\mathrm{p}_{\text {for trend }}=0.002$ & & $\mathrm{p}_{\text {fortrend }}=0.003$ \\
\hline Basketball players $\#$ & 1 & & 1 & \\
\hline Rowers & $1.6(0.6-4.5)$ & 0.401 & $2.5(0.9-6.7)$ & 0.068 \\
\hline Cyclists & $10.5(3.6-30.7)$ & $<0.001$ & $0.1(0.01-0.7)$ & 0.023 \\
\hline \multicolumn{3}{|l|}{$\mathrm{R}^{2}=38.7 \%$} & \multicolumn{2}{|l|}{$\mathrm{R}^{2}=36 \%$} \\
\hline
\end{tabular}


training by 2.6 times increased the risk for eccentric left ventricular hypertrophy), and cycling sport discipline compared to basketball $(\mathrm{OR}=10.5, \mathrm{p}<0.001)$. The probability of left ventricular concentric geometry was significantly less in cyclists compared to basketball players $(\mathrm{OR}=0.1$, $\mathrm{p}<0.05$ ) and significantly less in age of $14-15$ years compared to age of $16-17$ years $(\mathrm{OR}=0.3, \mathrm{p}<0.05)$. Concentric left ventricular geometry had tendency to increase by rowing sport compared to basketball $(\mathrm{OR}=2.5,95 \% \mathrm{CI}=0.9-6.7$; $\mathrm{p}=0.07)$.

\section{Discusion}

Cardiac adaptation to long-term physical load has been described as a physiological phenomenom $(10,22,26)$. On the other hand, moderate left ventricular hypertrophy may be confused with pathological disorders such as hypertrophic or dilated cardiomyopathy $(22,26,29)$. The data regarding impact of long-term exersice on left ventricular mass in children and adolescent athletes are relative scare. There are currently no well established criteria for determination of left ventricular hypertrophy in childhood by M-mode echocardiography. According Daniels et al a cutpoint for LV mass index is above the 95th percentile for LV mass index in normal children and adolescents (7, 8). Results of study demonstrated that half of athletes had developed left ventricular mass index above the 95th percentile. To distinguish "athletes heart" from LV pathologies, Doppler echocardiography is widely used. Diastolic function is preserved or even "supernormal" in athletes' heart $(14,17,22)$ in contrast to pathological LV hypertrophy, e.g., cardiomyopathy, in which impaired LV diastolic function. In our study athletes had higher E/A ratio compared to controls and there was no evidence of impaired LV diastolic function. Also, in our study no one athlete had reduced LV shortening fraction. It could suggest that left ventricular hypertrophy in children and adolescent athletes is a favorable result of adaptation to regular (systemic) physical training. On the other hand, we didn't use the tissue Doppler measurements which are necessary for complete assessments of LV diastolic function, and didn't measured other indices of LV systolic fraction, e.g. ejection fraction and stroke volume. So we could not details characterize LV systolic and diastolic function of athletes.

To our knowledge, evaluation of left ventricular geometry in children and adolescents athletes has not been previously reported. Although Petkowicz et al. (20), Petridis et al. (21) determined similar heart response to long term physical load in young athletes, other data observed that adolescent and adults differed from adults with respect to range of measurements left ventricular echocardiografic parameters
$(26,27)$. The study of 22 male prepubertal swimmers showed increased left ventricular wall thickness, without a significant change in the left ventricular end diastolic diameter in athletes compared to controls (3). The results of our study showed that 12-17 year-old male athletes have significantly greater absolute and indexed to body surface area and height left ventricular mass, left ventricular wall thickness and left ventricular internal diameter at end diastole, compared to controls. In young athletes aged 14 to 18 years Sharma et al. also reported the greater left ventricle mass, left ventricular wall thickness and left ventricular internal diastolic diameter, but there was no difference in the body size related wall thickness (26). In contrast, we observed a greater percentage difference left ventricular wall thickness than in left ventricular end diastolic diameter comparing athletes and control subjects. Relative wall thickness in athletes was increased also compared to controls. Our findings showed that left ventricular myocardium mass are increased mainly due to ventricular wall thickening. Importantly, left ventricular hypertrophy may start in prepubertal age as shown in this study. It suggest that in the initial phase of regular training the increase of the left ventricular internal diameter precedes the wall thickening.

Our study demonstrates that left ventricle hypertrophy was present in $47 \%$ of all athletes, predominantly (34\%) eccentric hypertrophy. Despite the fact that there was a greater percentage difference left ventricular wall thickness than in left ventricular end diastolic diameter comparing athletes and control subjects in our study, when we classified left ventricular hypertrophy in athletes according left ventricular mass index and relative wall thickness, a variety of left ventricular hypertrophy was seen. Distribution by left ventricular hypertrophy revealed eccentric hypertrophy in $34 \%$, concentric hypertrophy in $16 \%$ and concentric remodeling in $7 \%$ athletes. Petridis at al. assessed left ventricular echocardiographic parameters in 137 athletes of two age groups - 15-16 and 17-18 year-old. In their study greater myocardium mass was larger in both age groups (21). Osborn et al demonstrate left ventricular geometry in 41 professional tennis players with mean age of 23 and found that majority of athletes $(73 \%)$ had left ventricular hypertrophy predominantly eccentric left ventricular hypertrophy (18). It confirms results of our study, that prevalence of eccentric left ventricular geometry is higher in athletes. The reason why prevalence of left ventricular hypertrophy in our data was lower than in Osborn study might be the younger age of athletes and shorter training duration. The subjects in Osborn study were professional tennis players, athletes in our study belonged to various regional teams, so their training volume and schedule was different. 
Individual studies showed that cardiac adaptation may differ according the type of exercise $(5,6,10)$. More isotonic forms of exercise found in endurance sports tend to cause an increase in ventricular chamber dimensions, but with only mild but proportional increases in wall thickness. In contrast, isometric exercise, found in the predominantly strength trained sports, tend to increase wall thickness alone. Some endurance sports like cycling and rowing combines dynamic and static exercise and would be expected unique cardiac demand on athletes participating in this activity. However, cardiovascular adaptation in endurance athletes is different from ball-trained like basketball athletes. Apart technical skills, basketball training involves predominantly dynamic, both aerobic and anaerobic exercises $(9,10)$. Conditioning and training should emphasize short, quick bursts rather than long-distance running. This could reflect the cardiac response of basketball players. Structural cardiac adaptation of basketball players is moderate at best. As shown in resent studies, it is not possible to clearly separate a strength-trained from an endurance-trained athlete's heart and frequently athletes develop a left ventricular combination of cavity dilatation and increased wall thickness.

Our study shows, that there are considerably differences in LV geometry among athletes of different sporting discipline. Our data shows that effects related to physical load in cyclists on left ventricular geometry were seen predominantly as eccentric hypertrophy (54\%). It confirms the results received from other researches that found increased left ventricular mass in cyclists due to greater left ventricular internal diastolic diameter $(1,10)$. In the meta-analysis of male cyclists left ventricular end diastolic diameter, wall thickness and left ventricular mass were greater than in controls (10). Moreover, relative wall thickness in cyclists was enlarged compared to controls. In our study concentric left ventricular hypertrophy was only in $4 \%$ cyclists. It sugest that spectrum of left ventricular geometry in cyclists could be various. This could be explained by the fact that cycling is not only associated with a large increases in cardiac preload, which results eccentric hypertrophy, also involves static activity of the upper part of the body.

There are limited data that examine cardiovascular adaptation in children and adolescent rowers $(23,26)$. Cardiac structures of rowers involved in adult studies are different. The most studies conducted on adult athletes engaged in rowing revealed thicker myocardial walls in rowers than in athletes in other sports (10). Makan at al. indicated greater myocardial mass and left ventricular wall thickness in 15 year- old rowers compared to controls, but there was no difference in left ventricular diastolic diameter (15). Our findings confirmed that rowers revealed higher prevalen- ce of concentric left ventricular hypertrophy (41\%) than eccentric left ventricular hypertrophy $(21 \%)$ in rowers, that suggest that rower's cardiac adaptation to training is mainly due to thicker left ventricular walls. As shown in other studies, athletes participated in rowing are more associated with largest increase of left ventricular cavity dimensions $(10,22)$. We also observed eccentric left ventricular hypertrophy in $21 \%$ of rowers. Rowing includes the components of endurance and resistance training, but there is an upper and lower body imbalance that could influence to heart adaptation.

Basketball is the most common sport in Lithuania, but there is very limited studies focusing on the effect of training in children and adolescent basketball-players in Lithuania as in the entire world. Our data shows that most of the basketball-players manifested normal left ventricular geometry $(53 \%)$. The results of our study agree with reports, indicating that effects of basketball exercise on left ventricular structure are moderate and small $(10,27)$. Pellicia at al. demonstrated that basketball have moderate impact to left ventricular diastolic diameter (19). We found the similar distribution of eccentric and concentric left ventricular hypertrophy in basketball-players. This may be explained by the fact that during short breaks between different interval exercises increases systolic volume, which could be a stimulus for enlargement of left ventricular internal diameter in basketball-players. On other hand, in the training programs basketball players has a static exercise, which leads to increase afterload resulting in increase of left ventricular wall thickness without significant enlargement of left ventricle. Our subjects were 12-17 years involved and this point differs from the adult subjects of Pellicia study. We didn't assess each athletes training scheduler, playing position that could influence on left ventricular geometry in basket-ball players (9).

Left ventricular geometry response to exercise training in children and adolescent athletes is heterogeneous. Our multivariate analysis showed that the age was independent predictor eccentric and concentric left ventricular hypertrophy. Eccentric hypertrophy was significantly associated with training volume and cycling sport discipline. Evidence of eccentric hypertrophy was found after long term sprint training in adults (10). On the contrary, Venckunas et al. have demonstrated 23 male distance runners which increased their training volume from 8.0 to 12.5 hours/week without increasing the intensity. After one year period athletes had a greater left ventricular mass and wall thickness, but there was no increase in left ventricular end diastolic diameter (28). In our study concentric left ventricular geometry had tendency to increase by rowing sport compared to basket- 
ball. These findings confirm previously reported results from other studies confirming rowing increase concentrity of left ventricular (10). Training duration was not related to left ventricular hypertrophy. Possible explanation of this finding is that training duration is not a reliable index of intensity training (15).

Study limitations. In this study, our interest defines the effect of long-term training on LV geometry in children and adolescent athletes. The strength of our study is inclusion athletes of different age and sporting discipline. There are some limitations that need to be acknowledged and addressed regarding the present study. They include insufficient information to assess training intensity, training schedule, playing positions of athletes, a relatively small sample size, and a predominance of male subjects. Abnormal left ventricular geometry may therefore be affected not only by longterm physical load, but also by other factors such growing, maturation, fat-free body mass, systolic blood pressure at rest and during exercise and genetic predisposition to left ventricular hypertrophy $(25,26)$. The main limitation of our study are the absent analysis of these factors. For complete assessments of LV mass cardiac MRI and for diastolic function tissue Doppler measurements didn't used. Also LV ejection fraction and stroke volume which define LV systolic function were not evaluated. However, further studies are needed to confirm our results and to expand the echocardiographic assessment to include tissue Doppler echocardiographic assessment of left ventricular geometry and function in children and adolescent athletes $(22,25)$. Further studies are necessary to analyse effects of long-term exercise to left ventricle of children and adolescent athletes.

\section{Conclusion}

In conclusion, almost half of athletes (48\%) had left ventricle hypertrophy, predominantly eccentric hypertrophy, and the age was the important determinant of left ventricular hypertrophy (eccentric and concentric). Training volume and cycling sporting discipline were significantly associated with eccentric left ventricular hypertrophy.

\section{References}

1. Abergel E, Chatellier G, Hagege A. et al. Serial left ventricular adaptations in world-class professional cyclists. J Am Coll Cardiol 2004;44:144-149. http://dx.doi.org/10.1016/j.jacc.2004.02.057

2. Baggish AL, Wood MJ. Athlete's Heart and Cardiovascular Care of the Athlete: Scientific and Clinical Update. Circulation 2011;11(123):2723-2735. http://dx.doi.org/10.1161/CIRCULATIONAHA.110.981571

3. Ayabakan C, Akalin F, Mengütay S, Cotuk B, Odabas I, Ozüak A. Athlete's heart in prepubertal male swimmers. Cardiol Young 2006;16(1):61-66.
http://dx.doi.org/10.1017/S1047951105002106

4. Aaron L. Baggish, Malissa J. Wood Athlete's Heart and Cardiovascular Care of the Athlete Scientific and Clinical Update. Circulation. 2011; 123: 2723-2735. http://dx.doi.org/10.1161/CIRCULATIONAHA.110.981571

5. Barbier J, Ville N, Kervio G, Walther G, Carre F. Sports-specific features of athlete's heart and their relation to echocardiographic parameters. Herz 2006;31:531-543. http://dx.doi.org/10.1007/s00059-006-2862-2

6. Barbier J, Lebiller E, Ville N, Rannou-Bekono F, Carré F Relationships between sports-specific characteristics of athlete's heart and maximal oxygen uptake. Eur J Cardiovasc Prev Rehabil. 2006;13(1):115-21. http://dx.doi.org/10.1097/01.hjr.0000188243.46664.4c

7. Daniels SR, Loggie JM, Khoury P, Kimball TR. Left ventricular geometry and severe left ventricular hypertrophy in children and adolescents with essential hypertension. Circulation 1998; 97:1907-1911. http://dx.doi.org/10.1161/01.CIR.97.19.1907

8. Daniels S.R., T. R. Kimball, J. A. Morrison, P. Khoury, S. Witt and R.A. Meyer. Indexing left ventricular mass to account for differences in body size in children and adolescents without cardiovascular disease. Am. J. Cardiol 1995; 76:699-701. http://dx.doi.org/10.1016/S0002-9149(99)80200-8

9. Delextrat A, Cohen D. Effects of playing position on the anaerobic fitness of female basketball players. Journal of sport medicine and Physical Fitness 2007;43:432-436.

10. Fagard RH. Impact of different sports and training on cardiac structure and function. Cardiol Cli 1997;15(3):397-412. http://dx.doi.org/10.1016/S0733-8651(05)70348-9

11. Foster BJ, Gao T, Mackie AS, Zemel BS, Ali H, Platt RW, Colan SD. Limitation of expressing left ventricular mass relative to height and body surface area in children. J Am Soc Echocardiogr 2013; 26(4):410-8. http://dx.doi.org/10.1016/j.echo.2012.11.018

12. Hoogsteen J, Hoogeveen AR, Schaffers H, Wijn PFF, Hemel NM, Wall EE. Myocardial adaptation in different endurance sports: an echocardiographic study. The international journal of cardiovascular imaging, 2004;20(1), 19-26.

http://dx.doi.org/10.1023/B:CAIM.0000013160.79903.19

13. Lang RM, Bierig M, Devereux RB. et al. Recommendations for chamber quantification: a report from the American Society of Echocardiography's Guidelines and Standards Committee and the Chamber Quantification Writing Group, developed in conjunction with the European Association of Echocardiography, a branch of the European Society of Cardiology. J Am Echocardiography 2005;18:1440-63. http://dx.doi.org/10.1016/j.echo.2005.10.005

14. Mantziari A, VassilikosVP, Giannakoulas G. et al. Left ventricular function in elite rowers in relation to training-induced structural myocardial adaptation Scandinavian Journal of Medicine \& Science in Sports 2010; 20(3):428-433. http://dx.doi.org/10.1111/j.1600-0838.2009.00957.x

15. Makan J, Sharma S, Firoozi S, Whyte G, Jackson PG, McKenna WJ. Physiological upper limits of ventricular cavity size in highly trained adolescent athletes. Heart 2005 91(4):495-9. http://dx.doi.org/10.1136/hrt.2004.035121

16. Manolas VM, Pavlik G, Bánhegyi A, Faludi J, Sidó Z, Olexó Z. Echocardiographic changes in the development of the athlete's heart in 9 to 20-year-old male subjects. Acta Physiol Hung 
2001;88(3-4):259-270.

http://dx.doi.org/10.1556/APhysiol.88.2001.3-4.8

17. Mantziari A, Vassilikos VP, Giannakoulas G. et al. Left ventricular function in elite rowers in relation to training-induced structural myocardial adaptation. Scand J Med Sci Sports 2010 Jun;20(3):428-33 http://dx.doi.org/10.1111/j.1600-0838.2009.00957.x

18. Osborn RQ, Taylor WC, Oken K, Luzano M, Heckman M, Fletcher G Echocardiographic characterisation of left ventricular geometry of professional male tennis players. Br J Sports Med 2007;41(11):789-792.

http://dx.doi.org/10.1136/bjsm.2007.038661

19. Pelliccia A, Maron MS, Maron BJ. Assessment of left ventricular hypertrophy in a trained athlete: differential diagnosis of physiologic athlete's heart from pathologic hypertrophy. Prog Cardiovasc $2012 ; 54(5): 387-96$.

http://dx.doi.org/10.1016/j.pcad.2012.01.003

20.Petkowicz RO, Horowitz E S, Meyer F. Left Ventricular Structure in Male adolescent swimmers. Athletes. Medicine \& Science in Sports \& Exercis. 2003;35(5):319. http://dx.doi.org/10.1097/00005768-200305001-01763

21.Petridis I, Kneffel Zs, Kispeter Zs, Horvath P, Sido Z, Pavlic G. Echocardiographic characteristic adolescent junior male athletes of different sport events. Acta Physiologica Hungarica 2004;91(2):99-109.

http://dx.doi.org/10.1556/APhysiol.91.2004.2.2

22.Prior DL, La Gerche A. The athlete's heart. Heart 2012; 98(12):947-55.

http://dx.doi.org/10.1136/heartjnl-2011-301329

23. Quattrini FM, Di Paolo FM, Pisicchio C, CiardoR, Pelliccia A. A Young Rower with an Unusual Left Ventricular Hypertrophy. Sports Cardiology Casebook 2009; 175-182

http://dx.doi.org/10.1007/978-1-84882-042-5 25

24. Rickey PR, DiSessa G, Somes GW, Alpert BS, Jones DP. Left ventricular geometry in children and adolescent with primary hypertension. Am J Hypertens. 2010 January; 23(1): 24-29. http://dx.doi.org/10.1038/ajh.2009.164

25. Simsek Z, Gundogdu F, Alpaydin S, Gerek Z, Ercis S, Sen I, Akgün M, Karakelleoglu S. Analysis of athletes' heart by tissue Doppler and strain/strain rate imaging Int J Cardiovasc Imaging 2011 Jan; 27(1):105-11. http://dx.doi.org/10.1007/s10554-010-9669-1

26. Sharma S. Athlete's heart - effect of age, sex, ethnicity and sporting discipline. Exp Physiol 2003; 88(5):665-669. http://dx.doi.org/10.1113/eph8802624

27. Vasiliauskas D, Venckūnas T, Marcinkeviciene J, Bartkeviciene A. Development of structural cardiac adaptation in basketball players. Cardiovasc Prev Rehabil 2006;13 (6): 985-989. http://dx.doi.org/10.1097/01.hjr.0000238394.04600.fc

28. Venckunas T, Stasiulis A, Raugaliene R. Concentric myocardial hypertrophy after one year of increased training volume in experienced distance runners. British Journal of Sports Medicin 2006;40:706-9. http://dx.doi.org/10.1136/bjsm.2006.027813

29.Zaidi A, Sharma S. From athletes and arrhytmias to hypertrophic cardiomyopathy and congenital heart disease Future Cardiol. 2013;9 (1); 119-136 http://dx.doi.org/10.2217/fca.12.81

\section{2-17 METŲ SPORTININKŲ KAIRIOJO SKILVELIO GEOMETRIJOS POKYČIAI}

\section{A. Bartkevičienė}

Raktažodžiai: vaikai, sportininkai, kairysis skilvelis, geometrija, hipertrofija.

Santrauka

Dèl ilgalaikio fizinio krūvio persitvarko vaikų ir paaugliu kairiojo skilvelio geometrija. Sportuojančių vaikų ir paauglių kairiojo skilvelio geometrijos pokyčiams įtakos turi ne tik ilgalaikis fizinis krūvis, bet ir kiti veiksniai - amžius, antropometriniai duomenys, sporto šaka bei treniravimosi krūvis. Todèl ilgalaikio fizinio krūvio poveikio sportuojančių vaikų ir paauglių širdies geometrijai negalima atsieti nuo minètų veiksnių įtakos. Šio darbo tikslas - palyginti 12-17 metų dviratininkų, irkluotojų ir krepšininkų kairiojo skilvelio geometrijos pokyčius ir nustatyti veiksnius, turinčius įtakos kairiojo skilvelio geometrijai Metodai. Ištirti 167 vyriškosios lyties 12-17 metų sportininkai, iš jų 62 krepšininkai, 51 irkluotojas (akademinis irklavimas) ir 54 dviratininkai. Kontrolinę grupę sudare to paties amžiaus ir lyties 168 sveiki nesportuojantys vaikai ir paaugliai. Visiems tiriamiesiems atlikta M rěžimo, dvimatė ir doplerinè echokardiografija. Kairiojo skilvelio geometrijos analizei apskaičiuota kairiojo skilvelio miokardo mase (KSMM), miokardo masès indeksas (MMI) ir santykinis sienelès storis (SSS). Pagal MMI bei SSS viršutines ribines reikšmes nustatyta: normali KS geometrija, ekscentrinė KS hipertrofija, koncentrinis KS persimodeliavimas, koncentrinė KS hipertrofija. Rezultatai. Kairiojo skilvelio hipertrofija buvo nustatyta 48 proc. sportininkų, 34 proc. nustatyta ekscentrinè kairiojo skilvelio hipertrofija ir 16 proc. koncentrinè kairiojo skilvelio hipertrofija. Tik 7 proc sportininkų nustatytas koncentrinis kairiojo skilvelio persimodeliavimas. Dažniausiai irkluotojams nustatyta koncentrinė KS hipertrofija (38 proc.), dviratininkams - ekscentrinè kairiojo skilvelio hipertrofija (54 proc.). Tuo tarpu krepšininkams dažniausiai (53 proc.) pasitaikè normali kairiojo skilvelio geometrija. Pritaikius regresinę analizę, nustatyta, kad sportininkų koncentrinė kairiojo skilvelio hipertrofija priklausė tik nuo amžiaus, o ekscentrinès kairiojo skilvelio hipertrofijos nepriklausomi veiksniai buvo ne tik amžius, bet ir dviračio sporto šaka bei treniravimosi krūvis.

Išvados. 1. Beveik pusei sportininkų nustatyta kairiojo skilvelio hipertrofija. 2. Dažniausiai (34 proc.) pasitaikè ekscentrinè kairiojo skilvelio hipertrofija, rečiausiai (7 proc.) - koncentrinis kairiojo skilvelio persimodeliavimas. 3. Koncentrine kairiojo skilvelio hipertrofija priklausè tik nuo amžiaus, ekscentrinès kairiojo skilvelio hipertrofijos nepriklausomi veiksniai buvo ne tik amžius, bet ir dviračio sporto šaka bei treniravimosi krūvis.

Adresas susirašinèti: aldonabar@yahoo.com

Gauta 2015-09-07 